\title{
The Effect of Storytelling on Iranian EFL Learners' Vocabulary
}

\section{Retention}

\author{
Shahla Morsali ${ }^{1 *}$ \\ ${ }^{1}$ Department of English linguistics, Hacettepe University, Ankara, Turkey \\ *Shahla Morsali, E-mail: shmorsali@yahoo.com
}

Received: September 8, 2016 Accepted: September 22, $2016 \quad$ Online Published: October 7, 2016

doi:10.22158/selt.v4n4p416 URL: http://dx.doi.org/10.22158/selt.v4n4p416

\begin{abstract}
This paper presents the results of a study on utilizing two storytelling techniques, summarizing and strip story arrangement, in an EFL context. It focused on exploring which type of storytelling technique was more effective and thus could help EFL learners master the new words better. In was carried out in a private language school in Tehran, Iran. The participants were 105 learners who were selected from 160 elementary learners based on their performance on Oxford Placement Test as the test of homogenization. Three groups were formed, two experimental and one control group with 35 subjects in each. The learners in the summarizing group used the new words to summarize the stories in their written and spoken tasks and the learners in the other experimental group, strip story arrangement group, were asked to arrange some split sentences in their personal drafts. After thirty treatment sessions, the learners were given the posttest. The three groups' performances on the posttest were compared by one way ANOVA. The results showed that the learners in summarizing group performed better than strip story arrangement group and both groups outperformed the control group.
\end{abstract}

\section{Keywords}

storytelling, summarizing tasks, strip story arrangement tasks, EFL learners, vocabulary retention

\section{Introduction}

Vocabulary plays a crucial role in all EFL/ESL classrooms. It also has a pivotal role in four language skills, reading, writing, speaking, and listening and is essential for successful communication. Indeed, research suggests that lexical errors impede communication and comprehension more than grammatical errors and native speakers believe in lexical errors as more serious (Ellis, 1994). So it can be said that by employing effective strategies to teaching lexical items, EFL learners' proficiency level can be enhanced greatly in four language skills consequently. As Wilson and Anderson (1986) has rightly put it, without grammar very little can be conveyed but without vocabulary nothing. Due to its vital role in language acquisition and organization of syllabuses, various techniques have been employed to teach 
vocabulary and each technique approaches teaching vocabulary from a different point of view. In this regard Nation (2001) argues that vocabulary is acquired best through fully contextualized activities.

Short stories can provide contextualized tasks to enhance vocabulary learning. Employing short stories in EFL/ESL classrooms is a technique which has been addressed in various studies (Garvie, 1990; Wodinsky \& Nation, 1988; Laufer \& Hulstijn, 2001). Traditional approach to vocabulary teaching has been to present learners with a list of words, then to present them in a context and provide activities to reinforce the lexical items. However, research supports that instead of this traditional approach, learners can acquire new lexical items through stories either by hearing or reading them (Cho \& Choi, 2008; Elley, 1991; Krashan, 2004; Vivas, 1996; Wang \& Lee, 2007). Employing stories in the classroom setting can maximize students' involvement and make them more engaged in the process of learning. Stories provide a problem solving approach to vocabulary learning and by doing so; they make retention of the information possible for longer periods of time. According to Craik and Tulving (1975) retention depends on the elaborateness of the final encoding, with material more likely to be remembered when information is more deeply processed. The benefits of using stories in an EFL/ESL setting are twofold. It makes students to get more involved in the process of learning through a problem solving path and it also maximizes the chance of shifting attention from teacher to students and make them use their own imagination and accept responsibility for their own learning.

Employing story telling techniques in L2 classrooms can create a positive and challenging learning environment and provide a meaningful and comprehensible input. Language learners can easily benefit from storytelling strategies since they can aid them to develop the skills required for understanding the language and engage in thinking abilities. It can sharpen their memory; provide them with the opportunities to speak the language while integrating creative thinking, information, and imagination. Since stories are repetitive in nature, this can additionally maximize and reinforce the acquisition of new words.

The present study was carried out in order to implement two storytelling strategies- summarizing and strip story arrangement- for teaching vocabulary items to female elementary learners in a private language school. The main objectives of this study were to find out whether these strategies were effective in teaching the lexical items to EFL learners and if so, which one was more effective than the other.

\section{Review of the Related Literature}

Vocabulary teaching has evolved a lot through its entire history in the domain of language teaching and learning, with any method giving its own premises regarding what vocabulary teaching means. With an increased emphasis on reading skills as the major goal of language learning, large scale investigations were conducted in 1920s and 1930s to develop principles of vocabulary teaching and learning. As Celce-Murcia (2001) states, vocabulary teaching was neglected since it was taught that it could simply be left to take care of itself. However by the late 1970s and 1980 this view was challenged seriously. 
Chomsky's (1957) rejection of behavioristic notion of habit formation and later on with the introduction of sociolinguistics and pragmatic aspects to the field of EFL/ESL which was followed by the concept of communicative competence, teaching and learning of vocabulary have taken a different path than the past. This trend was also reinforced by computer-aided research and discourse studies into the field of language teaching.

Concerning vocabulary learning, Read (2004) distinguished two approaches to the learning of lexical items; incidental and intentional. Most works focus on the former and aim to explore to what extent learners can learn vocabulary items incidentally while engaged in other language learning tasks. Read (2004) argues furthermore that to maximize incidental vocabulary learning in EFL/ESL classrooms, teachers can provide students with the target lexical items through tasks and ask them to read only the texts that include the target vocabulary. In this regard, stories can provide rich contextualized sources for learners to learn vocabulary. Short stories equip teachers with the pedagogical tools which can be utilized to aid the four language skills. Pesola (1991) suggested storytelling as one of the most powerful tools for surrounding young learners with language. And Wilson (1997) recommended that by adding stories and storytelling in the curriculum, the level of learning can be improved in all four language skills.

As Goodman (1982) has stated story recalling is both a research tool since it yields large amount of data to give insights into readers' comprehension processes and it also functions as an instructional strategy that can lead to improvement in various language skills. In fact various scholars support using stories in EFL/ESL settings. Wright, Betterlidge and Buckby (1984) support using tales to teach vocabulary in EFL contexts. They believe by using tales teachers can create language-rich contexts where students are supposed to use the language for communicative purposes.

Murdoch (2002) states that if short stories selected and exploited appropriately, they can provide quality texts which can greatly enhance ELT courses for intermediate learners. He further provides activities such as writing dialogues or other writing tasks which instructors can create based on these stories. Lao and Krashen (2000) in their study at a Hong Kong university presented two groups of students with literacy and non-literacy texts. The group who had read literacy texts, showed better improvement in terms of reading skills and vocabulary.

Stories have also been used in digital format to enhance learners' listening skills. In a study conducted by Ramirez and Belmonte (2007) learners were exposed to digital stories in an EFL class. The results showed that learners in experimental group outperformed the control group in subsequent tests. The frequency with which new lexical items appear in the stories may also be a determinant factor in learning vocabulary through stories. Robbins and Ehri (1994) carried out a study on thirty kindergarten children to examine the effects of stories on learning new words where children were supposed to listen to an adult reading stories containing new words. The findings showed that the children learned the words contained in the stories more significantly than the words which have not been mentioned in stories. The results suggested story reading as an effective tool for building vocabulary. 
It is not just language skills which can be positively affected by stories, short stories can motivate learners at all levels of language proficiency. Elliot (1990) contends that literature is "motivationally effective" if learners can be engaged with its thoughts and emotions and appreciate its aesthetic qualities. Of course to achieve this goal, stories must be in line with the learners' language proficiency level to avoid frustrational reading (Schulz, 1981).

\section{Methodology}

\subsection{Participants}

Out of 160 learners, 105 of them were chosen based on their performance on the Oxford Placement Test (Appendix 1) and were divided into three groups: two experimental and one control groups. There were 35 learners in each group. Besides these participants, the Oxford Placement Test was piloted with 40 learners who had the same characteristics as the main subjects. The teacher-made test of vocabulary was piloted with 70 learners with the same characteristics. The participants' age range was between 14-18, and all of them were female and had already covered the basic levels of the book series "PACESETTER" which at the time of study was taught at all Kish Language Schools in Iran. The class was held three days a week, two hours each day.

\subsection{Instrumentation}

The Oxford Placement Test: was piloted with 40 students prior to the treatment. With a reliability index of $0.86(\mathrm{KR}-21=0.86)$, the test was considered reliable enough to be used for the homogenization of the subjects. The time allocated to this test was 70 minutes and it consisted of three parts: 50 items of vocabulary and grammar, reading, and writing. All the items in the grammar and vocabulary and reading part were weighed by a single credit with no negative point for wrong answers (Appendix 1). A teacher-made test of vocabulary which involved 60 vocabulary items from the book "Anecdotes in American English" written by L.A. Hill was piloted with 70 learners. The reliability of this test came out to be $0.90(\mathrm{KR}-21=0.90)$. This test was used both as the pretest and posttest of the study. The learners were supposed to write the meaning of the words either in Farsi or provide a synonym in English. This test was administered to ensure that the vocabulary items chosen for the study were unknown to the learners. The time allocated to this test was 40 minutes; each item was weighed by a single credit with no negative point for wrong answers.

Besides the book series "PACESETTER" written by Derek Strange and Diane Hall which was the main course-book, the book "Anecdotes in American English" by L.A. Hill was used in the class to teach the vocabulary items. Almost all the chapters were covered during the course. Each session, the teacher allocated 30 minutes to teaching of these items and treatment stage.

\subsection{Procedure}

The research started with piloting phase in which both the Oxford Placement Test and teacher-made vocabulary test were piloted. The reliability of the placement test was 0.86 and the reliability index of the vocabulary test was 0.90 . 
After piloting phase, the treatment phase started as sequenced below:

The Oxford Placement Test was given to 160 participants at the beginning of the course in order to choose the participants of the main study. The students whose scores fell one SD above and below the mean were considered as the main subjects of the study. That is, out of 160 learners who took the test, 105 learners were considered homogeneous enough for the purpose of the study. The subjects were divided into three groups: two experimental and one control groups with 35 learners in each.

The teacher-made vocabulary test was administered to the participants of the study (it is worth mentioning that all 160 learners participated in the study, however only the scores of those main participants were counted in statistical analysis). It was given the session after the administration of the placement test.

As was mentioned before, there were two experimental groups- summarizing and strip story arrangement group- and one control group with 35 learners in each. In the treatment stage, the teacher started the session with teaching the new words (teaching of the new words lasted 24 sessions with one or two chapters for each session). Some aspects of the new words such as pronunciation and parts of speech were also taught to ensure maximum learning.

In one experimental group, namely strip story arrangement group, the teacher split some sequenced sentences of the story which involved the new vocabulary items which had already been taught to the participants. The subjects in this group were required to arrange the sentences in their personal drafts. In the other experimental group, summarizing group, the learners were to summarize the stories with the new words included. The teacher collected the writing tasks in both groups and later provided them with some feedback.

After the treatment sessions were over, on the $30^{\text {th }}$ session, the posttest was administered along with the students' final exam. There was a two-week gap between the end of the treatment and the administration of the vocabulary retention posttest. The control group did not receive any treatment.

There was no random assignment or selection of the participants, so the research enjoyed a Quasi-experimental design with summarizing and strip story arrangement tasks as the independent variables and vocabulary retention as the dependant variable. The proficiency, gender, and age of the participants were control variables. One-way ANOVA was run to analyze the data. The statistical analysis is discussed in the coming section.

\section{Statistical Analysis}

This study aimed to explore the following research questions:

1- Does summarizing task have any significant effects on vocabulary retention of Iranian EFL learners?

2- Does strip story arrangement task have any significant effects on vocabulary retention of Iranian EFL learners? 
3- Which is more effective- summarizing or strip story arrangement-on enhancing Iranian EFL learners' vocabulary retention?

To answer these questions, the following null hypotheses were posed:

$\mathrm{H}_{01}$. Summarizing task does not have any significant effects on vocabulary retention of Iranian EFL learners.

$\mathrm{H}_{02}$. Strip story arrangement task does not have any significant effects on vocabulary retention of Iranian EFL learners.

$\mathrm{H}_{03}$. There is not any significant difference between the effects of summarizing and strip story arrangement tasks on Iranian EFL learners' vocabulary retention.

The above mentioned hypotheses were analyzed using one-way analysis of variances (one-way ANOVA) which has two main assumptions; normality of the data and homogeneity of the variances of the groups. The latter will be discussed when reporting the main results, although if the sample sizes are equal — as is the case in this study — there is no need to worry about the violation of this assumption (Bachman, 2005; Pallant, 2011; Field, 2013). The normality of the present data was probed through Kolmogorov-Smirnov (KS Test) and skewness and kurtosis ratios.

As displayed in Table 1, the results of the KS Test $(\mathrm{p}>.05)$ indicated that the assumption of normality was met.

Table 1. Tests of Normality; Kolmogorov-Smirnov Test

\begin{tabular}{llllllll}
\hline & & \multicolumn{3}{l}{ Kolmogorov-Smirnov } & \multicolumn{3}{l}{ Shapiro-Wilk } \\
\cline { 3 - 8 } Group & & Statistic & Df & Sig. & Statistic & Df & Sig. \\
\hline \multirow{2}{*}{ Strip Story } & Pretest & .093 & 35 & .200 & .984 & 35 & .891 \\
& Posttest & .102 & 35 & .200 & .947 & 35 & .090 \\
\multirow{3}{*}{ Summarizing } & Pretest & .123 & 35 & .199 & .981 & 35 & .780 \\
& Posttest & .101 & 35 & .200 & .965 & 35 & .313 \\
\multirow{3}{*}{ Control } & Pretest & .146 & 35 & .057 & .945 & 35 & .080 \\
& Posttest & .108 & 35 & .200 & .969 & 35 & .427 \\
\hline
\end{tabular}

The ratios of skewness and kurtosis over their respective standard errors were lower than the absolute value of 1.96 (Table 2) indicates the normality of the present data.

Table 2. Descriptive Statistics

\begin{tabular}{lllllllll}
\hline & & $\mathrm{N}$ & \multicolumn{3}{c}{ Skewness } & \multicolumn{3}{c}{ Kurtosis } \\
\cline { 3 - 8 } Group & & Statistic & Statistic & Std. Error & Ratio & Statistic & Std. Error & Ratio \\
\hline \multirow{2}{*}{ Strip Story } & Pretest & 35 & .179 & .398 & 0.45 & -.311 & .778 & -0.40 \\
& Posttest & 35 & .418 & .398 & 1.05 & -.858 & .778 & -1.10 \\
\hline
\end{tabular}




\begin{tabular}{lllllllll}
\hline \multirow{2}{*}{ Summarizing } & Pretest & 35 & -.191 & .398 & -0.48 & -.287 & .778 & -0.37 \\
& Posttest & 35 & -.333 & .398 & -0.84 & -.712 & .778 & -0.92 \\
\multirow{2}{*}{ Control } & Pretest & 35 & .128 & .398 & 0.32 & -.944 & .778 & -1.21 \\
& Posttest & 35 & .091 & .398 & 0.23 & .006 & .778 & 0.01 \\
\hline
\end{tabular}

The analysis is presented as it has appeared in the methodology section, starting with the piloting phase then moving to the treatment phase.

\subsection{Piloting of Oxford Placement Test}

Table 3 displays the results of the OPT piloting. The KR-21 reliability index was .86 .

Table 3. Descriptive Statistics; Piloting OPT

\begin{tabular}{lcclc}
\hline & $\mathrm{N}$ & Mean & Std. Deviation & Variance \\
\hline OPT & 40 & 26.85 & 8.977 & 80.592 \\
KR-21 & .86 & & & \\
\hline
\end{tabular}

\subsection{Piloting of Vocabulary Test}

Table 4 presents the results of the vocabulary piloting. The KR-21 reliability index turned out to be 90 .

Table 4. Descriptive Statistics; Piloting Vocabulary

\begin{tabular}{lcclc}
\hline & N & Mean & Std. Deviation & Variance \\
\hline Pilot-Vocab & 70 & 19.06 & 10.592 & 112.200 \\
KR-21 & .90 & & & \\
\hline
\end{tabular}

\subsection{Oxford Placement Test (Homogenizing groups)}

A one-way ANOVA was run to compare the strip story, summarizing and control groups on the Oxford Placement Test in order to homogenize them in terms of their general language proficiency prior to the administration of the treatment. Before discussing the results, it should be mentioned that the assumption of homogeneity of variances was met $(F(2,102)=.023, \mathrm{p}=.977)$ (Table 5$)$.

Table 5. Test of Homogeneity of Variances

\begin{tabular}{llll}
\hline Levene Statistic & df1 & df2 & Sig. \\
\hline .023 & 2 & 102 & .977 \\
\hline
\end{tabular}

As shown in Table 6, the strip story $(\mathrm{M}=18.89, \mathrm{SD}=3.93,95 \% \mathrm{CI}[17.53,20.24])$, summarizing $(\mathrm{M}=$ $19.57, \mathrm{SD}=3.81,95 \% \mathrm{CI}[18.26,20.88])$ and control $(\mathrm{M}=18.80, \mathrm{SD}=4.11,95 \% \mathrm{CI}[17.39,20.21])$ groups had almost the same means on the OPT. 
Table 6. Descriptive Statistics; Oxford Placement Test by Groups

\begin{tabular}{lllllll} 
& \multirow{2}{*}{$\mathrm{N}$} & Mean & Std. Deviation & Std. Error & \multicolumn{2}{l}{$95 \%$ Confidence Interval for Mean } \\
\cline { 6 - 7 } & & & & Lower Bound & Upper Bound \\
\hline Strip Story & 35 & 18.89 & 3.939 & .666 & 17.53 & 20.24 \\
\multicolumn{2}{l}{ Summarizing 35 } & 19.57 & 3.814 & .645 & 18.26 & 20.88 \\
Control & 35 & 18.80 & 4.115 & .695 & 17.39 & 20.21 \\
Total & 105 & 19.09 & 3.935 & .384 & 18.32 & 19.85 \\
\hline
\end{tabular}

The results of one-way ANOVA $\left(\mathrm{F}(2,102)=.399, \mathrm{p}=.672, \omega^{2}=.012\right.$ representing a weak effect size $)$ (Table 7) indicated that there were not any significant differences between the three groups' means on the OPT. Thus it is safe to assume that they were homogenous in terms of their general language proficiency prior to the administration of the treatment.

Table 7. One-Way ANOVA; Oxford Placement Test by Groups

\begin{tabular}{llllll}
\hline & Sum of Squares & Df & Mean Square & F & Sig. \\
\hline Between Groups & 12.514 & 2 & 6.257 & .399 & .672 \\
Within Groups & 1597.714 & 102 & 15.664 & & \\
Total & 1610.229 & 104 & & & \\
\hline
\end{tabular}

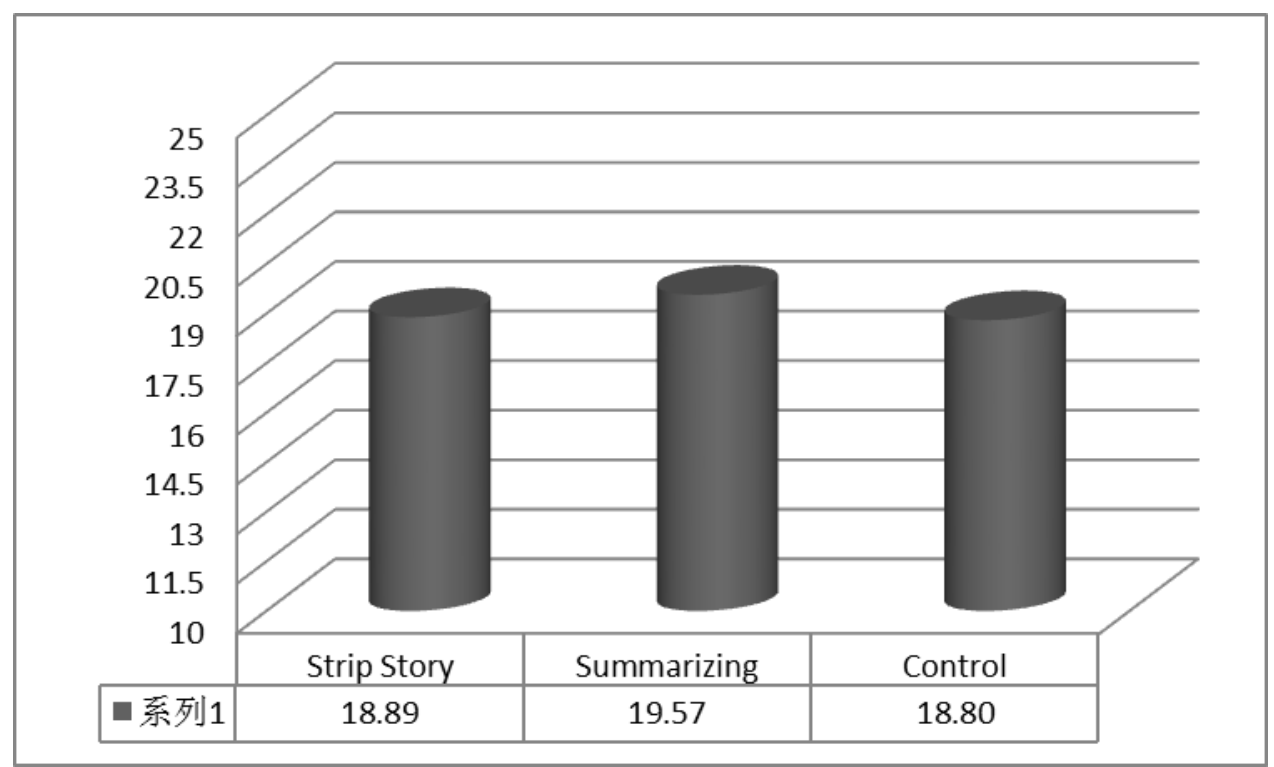

Figure 1. Means on Oxford Placement Test 


\subsection{Pretest of Vocabulary}

A one-way ANOVA was run to compare the strip story, summarizing and control groups on the pretest of vocabulary in order to homogenize them in terms of their vocabulary knowledge prior to the administration of the treatment. Before discussing the results, it should be mentioned that the assumption of homogeneity of variances was met $(\mathrm{F}(2,102)=.418, \mathrm{p}=.660)$ (Table 8$)$.

Table 8. Test of Homogeneity of Variances

\begin{tabular}{llll}
\hline Levene Statistic & df1 & df2 & Sig. \\
\hline .418 & 2 & 102 & .660 \\
\hline
\end{tabular}

As shown in Table 9, the strip story $(\mathrm{M}=7.74, \mathrm{SD}=2.85,95 \% \mathrm{CI}[6.76,8.72])$, summarizing $(\mathrm{M}=$ $6.69, \mathrm{SD}=3.06,95 \% \mathrm{CI}[5.63,7.74])$ and control $(\mathrm{M}=8.11, \mathrm{SD}=2.62,95 \% \mathrm{CI}[7.21,9.01])$ groups had almost the same means on the pretest of vocabulary.

Table 9. Descriptive Statistics; Pretest of Vocabulary by Groups

\begin{tabular}{lllllll}
\hline & \multirow{2}{*}{$\mathrm{N}$} & Mean & Std. Deviation & Std. Error & \multicolumn{2}{l}{ 95\% Confidence Interval for Mean } \\
\cline { 7 - 8 } & & & & & Lower Bound & Upper Bound \\
\hline Strip Story & 35 & 7.74 & 2.853 & .482 & 6.76 & 8.72 \\
Summarizing & 35 & 6.69 & 3.066 & .518 & 5.63 & 7.74 \\
Control & 35 & 8.11 & 2.621 & .443 & 7.21 & 9.01 \\
Total & 105 & 7.51 & 2.889 & .282 & 6.96 & 8.07 \\
\hline
\end{tabular}

The results of one-way ANOVA $\left(F(2,102)=2.36, p=.099, \omega^{2}=.025\right.$ representing a weak effect size $)$ indicated that there were not any significant differences between the three groups' means on the pretest of vocabulary. Thus it can be said that they were homogenous in terms of their vocabulary knowledge prior to the administration of the treatment.

Table 10. One-Way ANOVA; Pretest of Vocabulary by Groups

\begin{tabular}{llllll}
\hline & Sum of Squares & Df & Mean Square & F & Sig. \\
\hline Between Groups & 38.457 & 2 & 19.229 & 2.364 & .099 \\
Within Groups & 829.771 & 102 & 8.135 & & \\
Total & 868.229 & 104 & & & \\
\hline
\end{tabular}




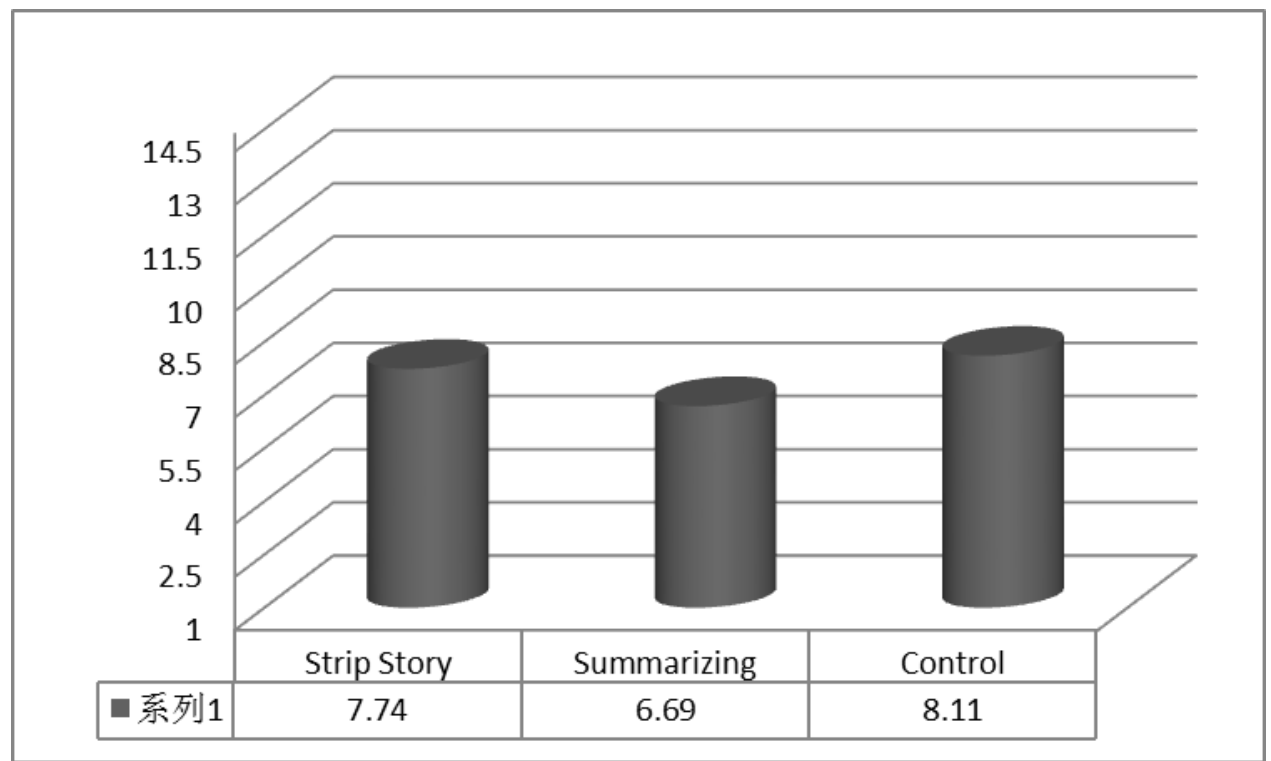

Figure 2. Mean Scores on Pretest of Vocabulary by Groups

\subsection{Posttest of Vocabulary}

A one-way ANOVA plus post-hoc Scheffe's tests were run to compare the strip story, summarizing and control groups on the posttest of vocabulary in order to probe the null-hypotheses posed in this study. Before discussing the results, it should be mentioned that the assumption of homogeneity of variances was not met $(\mathrm{F}(2,102)=9.83, \mathrm{p}=.000)($ Table 6$)$. As it was mentioned above, there was no need to worry about the violation of this assumption because the samples sizes were equal; although to be on the safe side, the results of the Brown-Forsythe's test was also reported.

Table 11. Test of Homogeneity of Variances

\begin{tabular}{llll}
\hline Levene Statistic & df1 & df2 & Sig. \\
\hline 9.833 & 2 & 102 & .000 \\
\hline
\end{tabular}

As shown in Table 12, the strip story $(\mathrm{M}=26.57, \mathrm{SD}=7.06,95 \% \mathrm{CI}[24.14,29])$ had the highest mean on the posttest of vocabulary. That was followed by the summarizing $(\mathrm{M}=22.43, \mathrm{SD}=7.02$, $95 \% \mathrm{CI}[20.02,24.84])$ and control $(\mathrm{M}=11.31, \mathrm{SD}=3.50,95 \% \mathrm{CI}[10.11,12.52])$ groups had the lowest mean.

Table 12. Descriptive Statistics; Posttest of Vocabulary by Groups

\begin{tabular}{lllllll}
\hline & \multirow{2}{*}{ N } & Mean & Std. Deviation & Std. Error & \multicolumn{2}{l}{ 95\% Confidence Interval for Mean } \\
\cline { 6 - 7 } & & & & Lower Bound & Upper Bound \\
\hline Strip Story & 35 & 26.57 & 7.064 & 1.194 & 24.14 & 29.00 \\
\hline
\end{tabular}




\begin{tabular}{lllllll}
\hline Summarizing & 35 & 22.43 & 7.022 & 1.187 & 20.02 & 24.84 \\
Control & 35 & 11.31 & 3.504 & .592 & 10.11 & 12.52 \\
Total & 105 & 20.10 & 8.851 & .864 & 18.39 & 21.82 \\
\hline
\end{tabular}

The results of one-way ANOVA $\left(\mathrm{F}(2,102)=58.62, \mathrm{p}=.000, \omega^{2}=.523\right.$ representing a large effect size $)$ (Table 8 ) indicated that there were significant differences between the three groups' means on the posttest of vocabulary.

Table 13. One-Way ANOVA; Posttest of Vocabulary by Groups

\begin{tabular}{llllll}
\hline & Sum of Squares & Df & Mean Square & F & Sig. \\
\hline Between Groups & 4357.162 & 2 & 2178.581 & 58.621 & .000 \\
Within Groups & 3790.686 & 102 & 37.164 & & \\
Total & 8147.848 & 104 & & & \\
\hline
\end{tabular}

The results of post-hoc Scheffe's test (Table 9) indicated that;

A: The summarizing group $(M=22.43)$ significantly outperformed the control group $(M=11.31)$ on the posttest of vocabulary ( $\mathrm{MD}=11.11 ., \mathrm{p}=.000$ ). Thus the second null-hypothesis as summarizing task did not have any significant effects on vocabulary retention of Iranian EFL learners was rejected.

B: The strip story group $(M=26.57)$ significantly outperformed the control group $(M=11.31)$ on the posttest of vocabulary ( $\mathrm{MD}=15.25, \mathrm{p}=.000$ ). Thus the first null-hypothesis as strip story arrangement task did not have any significant effects on vocabulary retention of Iranian EFL learners was rejected.

Table 14. Multiple Comparisons; Posttest of Vocabulary by Groups

\begin{tabular}{llllllll}
\hline & & \multirow{2}{*}{ Mean Difference (I-J) } & Std. Error Sig. & \multicolumn{2}{l}{$95 \%$ Confidence Interval } \\
\cline { 6 - 7 } (I) Group & (J) Group & & & & Lower Bound & Upper Bound \\
\hline \multirow{2}{*}{ Strip Story } & Summarizing & $4.143^{*}$ & 1.457 & .020 & .52 & 7.76 \\
& Control & $15.257^{*}$ & 1.457 & .000 & 11.64 & 18.88 \\
\multirow{2}{*}{ Summarizing } & Control & $11.114^{*}$ & 1.457 & .000 & 7.49 & 14.73 \\
\hline
\end{tabular}

*. The mean difference is significant at the 0.05 level.

B: The strip story group $(M=26.57)$ significantly outperformed the summarizing group $(M=22.43)$ on the posttest of vocabulary ( $\mathrm{MD}=4.14, \mathrm{p}=.000$ ). Thus the third null-hypothesis as there was not any significant difference between the effects of summarizing and strip story arrangement tasks on Iranian EFL learners' vocabulary retention was rejected. 


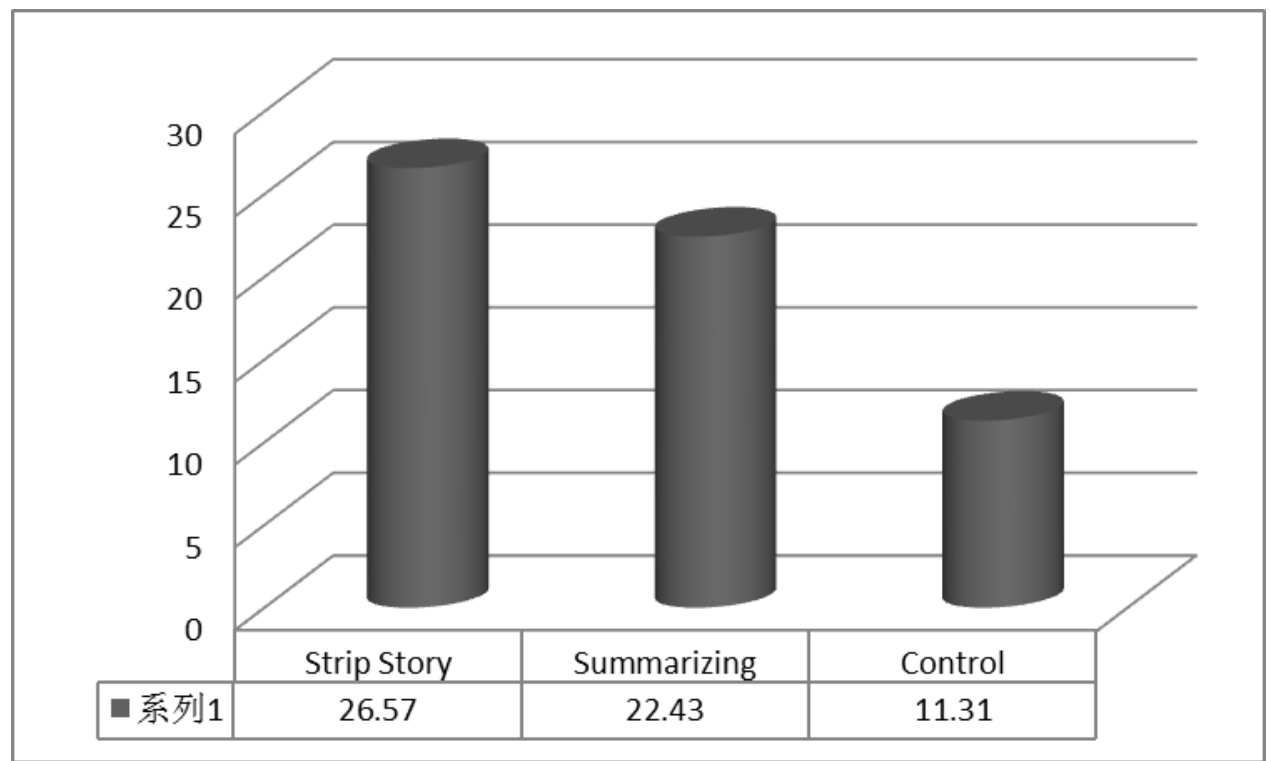

Figure 3. Mean Scores on Posttest of Vocabulary by Groups

\section{Brown-Forsythe's Test}

Brown-Forsythe's test $(\mathrm{F}(2,83.32)=58.62, \mathrm{p}=.000)$ also indicated significant differences between the three groups' means on the posttest. Table 15 presents the results in this regard.

Table 15. Robust Tests of Equality of Means

\begin{tabular}{lllll}
\hline & Statistic $^{\mathrm{a}}$ & $\mathrm{df1}$ & $\mathrm{df2}$ & Sig. \\
\hline Brown-Forsythe & 58.621 & 2 & 83.320 & .000 \\
\hline
\end{tabular}

\section{Discussion}

The purpose of this study was to investigate the effects of two storytelling strategies-summarizing and strip story arrangement- on vocabulary retention of female elementary EFL learners. It also aimed to determine which strategy leads to more improvement regarding vocabulary learning and thus yields better learning outcomes.

Based on the data analysis and the findings, enough evidence was observed to reject the null hypothesis which stated that there is not any significant difference among the effects of using summarizing and strip story arrangement tasks on EFL learners' vocabulary retention. It means that the two story making tasks proved to be effective on vocabulary retention of two experimental groups. It must be mentioned that strip story group significantly outperformed summarizing group and both experimental groups outperformed the control group. According to the results, it can be noted that storytelling techniques can benefit teachers and equip them with sound tools to make learning of new vocabulary items more meaningful and effective. 
Each research faces limitations which may affect its generalizability. However, there is always room for improvement and better studies. Concerning the limitations of this research, some ideas can be suggested for further works. This study focused on female elementary learners in a private language school in Iran. Similar studies can be carried out with male learners, or learners with other language proficiency levels or in public schools. From a myriad of storytelling techniques just two of them were utilized in this study. Other techniques can also be studied to examine if they yield the same or different results. And the last but not least, the researcher applied a quantitative method to gather the data of the study. Utilizing qualitative methods may shed more light on the findings and open new doors for further studies from a different perspective.

\section{Conclusion}

Lack of vocabulary means lack of meaningful or successful communication. In this regard, employing effective strategies to approach vocabulary teaching is of utmost importance. It can be stated that the pivotal role of storytelling in EFL classrooms cannot be denied. It was proved that using storytelling techniques in EFL classroom can assist learners with the retention of the lexical items. So storytelling is a powerful pedagogical tool which, if employed properly, can lead to successful vocabulary learning and retention. Stories can provide meaningful, comprehensible, and interesting input for language learners and the strategies which make use of stories such as summarizing and strip story arrangement, can aid learners expand their vocabulary knowledge. As the researcher observed, during the tasks the focus was more on students than on teacher and the class enjoyed a student-centered rather than a traditional teacher-centered environment. Incorporating summarizing and strip story arrangement tasks in EFL settings require learners to work collaboratively and use all their linguistic resources to do the tasks. I believe this is the most precious implication that this study may have for EFL/ESL teachers and syllabus designers.

\section{References}

Celce Murcia, M. (2001). Teaching English as second or foreign language (3rd ed.). The United States of America: Heinle \& Heinle, a Division of Thomson Learning.

Cho, K.-S., \& Choi, D.-S. (2008). Are read-alouds and free reading "Natural Partners". Knowledge Quest, 36(5), 1-5.

Chomsky, N. (1957). Syntactic Structures. The Hague: Mouton.

Craik, F., \& Tulving, E. (1975). Depth of Processing and the retention of words in episodic memory. Journal of Experimental Psychology: General, 104, 268-294. http://dx.doi.org/10.1037/0096-3445.104.3.268

Elley, W. (1991). Acquiring literacy in a second language: The effect of book- based programs. Language learning, 41, 375-411. http://dx.doi.org/10.1111/j.1467-1770.1991.tb00611.x

Elliott, R. (1990). Encouraging reader-response to literature in ESL situations. ELT Journal, 44(3), 
191-198. http://dx.doi.org/10.1093/elt/44.3.191

Ellis, N. C. (1994). Vocabulary acquisition: The implicit ins and outs of explicit cognitive mediation. In N. Ellis (Ed.), Implicit and explicit learning of language (pp. 211-282). London: Academic Press.

Garvie, E. (1990). Story as vehicle: Teaching English to young children. Clevedon, England: Multilingual matters.

Goodman, Y. M. (1982). Retellings of literature and the comprehension process. Theory Into Practice, Institute of Educational Sciences, 21(4), 300-307. http://dx.doi.org/10.1080/00405848209543022

Krashen, S. (2004). The Power of Reading: Insights from the Research. Portsmouth, NH: Heinemann.

Lao, C. Y., \& Krashen, S. (2000). The impact of popular literature study on literacy development in EFL: More evidence for the power of reading. System, 28, 261-270. http://dx.doi.org/10.1016/S0346-251X(00)00011-7

Laufer, B., \& Hulstijn. (2001). Incidental vocabulary acquisition in a second language: The construct of task- induced involvement. Applied linguistics, 22, 1-26. http://dx.doi.org/10.1093/applin/22.1.1

Murdoch, G. (2002). Exploiting well-known short stories for language skills development. IATEFL LCS SIG Newsletter, 23, 9-17.

Nation, I. S. P. (2001). Learning vocabulary in another language. Cambridge: Cambridge University Press. http://dx.doi.org/10.1017/CBO9781139524759

Pesola, C. A. (1991). Culture in the elementary foreign language classroom. Foreign Language Annals, 24(4), 331-346. http://dx.doi.org/10.1111/j.1944-9720.1991.tb00478.x

Ramirez, D., \& Belmonte. (2007). Using digital stories to improve listening comprehension with Spanish young learners of English. Language Learning and Technology Journal, 12(14), 1-8.

Read, J. (2004). Research in teaching vocabulary. Annual Review of Applied Linguistics, 24, $146-161$. http://dx.doi.org/10.1017/s0267190504000078

Robbins, C., \& Ehri, L. C. (1994). Listening to stories helps kindergartners learn new vocabulary words. Journal of educational psychology, 86, 54-64. http://dx.doi.org/10.1037/0022-0663.86.1.54

Schulz, R. A. (1981). Literature and readability: Bridging the gap in foreign language reading. The Modern Language Journal, 65, 43-53. http://dx.doi.org/10.1111/j.1540-4781.1981.tb00952.x

Vivas, E. (1996). Effects of story reading on language. Language learning, 46, 189-216. http://dx.doi.org/10.1111/j.1467-1770.1996.tb01234.x

Wang, F.-Y., \& Lee, S.-Y. (2007). Storytelling is the bridge. International Journal of Foreign Language Teaching, 3(2), 30-35.

Wilson, P. T., \& Anderson, R. C. (1986). What they don't know will hurt them: The role of prior knowledge in comprehension. In J. Orasanu (Ed.), Reading comprehension: From research to practice (pp. 31-48). Hillsdale, NJ: Lawrence Erlbaum Associates.

Wodinsky, M., \& Nation, P. (1988). Learning from graded readers. Reading in a foreign language, 5(1), $1-155$.

Wright, A., Betteridge, D., \& Buckby, M. (1984). Games for language learning (2nd ed.). Cambridge Published by SCHOLINK INC. 
Cambridge University Press.

\section{Appendix 1}

\section{Solutions}

\section{Introduction}

This placement test is intended to help teachers decide which level of Solutions, Elementary, Pre-Intermediate or Intermediate, is the most suitable for their students. It should be given at the beginning of the school year.

Solutions placement test has been developed after consultation with teachers and is designed to assess students' knowledge of the key language as well as their receptive and productive skills. This will enable teachers to have a greater understanding of what level their students are at.

The test contains:

- 50 multiple choice questions which assess students' knowledge of key grammar and vocabulary from elementary to intermediate levels.

- A reading text with 10 graded comprehension questions.

- An optional writing task that assesses students' ability to produce the language.

The 50 multiple choice questions and the reading task are designed to be done together in a 45-minute lesson. The writing task can be done in the following lesson and should take approximately 20 minutes.

\section{Interpreting scores}

\begin{tabular}{lllll}
\hline & Total & Elementarv & Pre-Intermediate & Intermediate \\
\hline Grammar \& Vocabulary & 50 & $0-20$ & $21-30$ & $31+$ \\
Reading & 10 & $0-4$ & $5-7$ & $8+$ \\
Writing & 10 & $0-4$ & $5-7$ & $8+$ \\
\hline
\end{tabular}

This table acts as a guideline for teachers when choosing which level of Solutions is suitable for their students. Reading and writing scores are included separately so that teachers who choose not to include these tasks in the placement test can still make an accurate assessment of their students' abilities.

Where there is a discrepancy in the level attained in the different parts of the test, a student's score for grammar and vocabulary should take precedence. Alternatively, a teacher may wish to conduct an additional oral interview to confirm the result.

Students whose scores fall on the borderlines should be placed according to the level of the rest of the class and monitored closely at the start of the course.

Great Clarendon Street, Oxford ox2 6dp

Oxford University Press is a department of the University of Oxford.

It furthers the University's objective of excellence in research, scholarship, and education by publishing worldwide in Oxford New York. 
Auckland Cape Town Dar es Salaam Hong Kong Karachi Kuala Lumpur Madrid Melbourne Mexico City Nairobi New Delhi Shanghai Taipei Toronto

With offices in

Argentina Austria Brazil Chile Czech Republic France Greece Guatemala Hungary Italy Japan Poland Portugal Singapore South Korea Switzerland Thailand Turkey Ukraine Vietnam

oxford and oxford English are registered trade marks of Oxford University Press in the UK and in certain other countries.

(C) Oxford University Press 2007

The moral rights of the author have been asserted Database right Oxford University Press (maker) First published 2007

20112010200920082007

10987654321

All rights reserved. No part of this publication may be reproduced, stored in a retrieval system, or transmitted, in any form or by any means, without the prior permission in writing of Oxford University Press (with the sole exception of photocopying carried out under the conditions stated in the paragraph headed "Photocopying"), or as expressly permitted by law, or under terms agreed with the appropriate reprographics rights organization. Enquiries concerning reproduction outside the scope of the above should be sent to the ELT Rights Department, Oxford University Press, at the address above.

You must not circulate this book in any other binding or cover and you must impose this same condition on any acquirer.

\section{Photocopying}

The Publisher grants permission for the photocopying of those pages marked "photocopiable" according to the following conditions. Individual purchasers may make copies for their own use or for use by classes that they teach. School purchasers may make copies for use by staff and students, but this permission does not extend to additional schools or branches

Under no circumstances may any part of this book be photocopied for resale.

Any websites referred to in this publication are in the public domain and their addresses are provided by Oxford University Press for information only. Oxford University Press disclaims any responsibility for the content.

\section{Grammar and Vocabulary}

Complete the sentences with the correct answers.

1 My sister very tired today.

$\mathrm{A}$ be $\mathrm{B}$ am $\mathrm{C}$ is $\mathrm{D}$ are

2 His _ is a famous actress.

A aunt B uncle $\mathrm{C}$ grandfather D son

3 I'd like to be a _ and work in a hospital.

A lawyer B nurse C writer D pilot

Published by SCHOLINK INC. 
$4 \mathrm{We}$ _like rap music.

A doesn't $\mathrm{B}$ isn't $\mathrm{C}$ aren't $\mathrm{D}$ don't

5 There _a lot of water on the floor. What happened?

$\mathrm{A}$ are $\mathrm{B}$ is $\mathrm{C}$ be $\mathrm{D}$ am

$6 \mathrm{He} \_\mathrm{TV}$ at the moment.

A watches B is watching $\mathrm{C}$ watched $\mathrm{D}$ has watching

7 Helen is very _.. She doesn't go out a lot.

A bored $\mathrm{B}$ confident $\mathrm{C}$ angry $\mathrm{D}$ shy

8 Did you _to the beach yesterday?

A went $B$ were $C$ go $D$ goed

9 Have you got _ orange juice? I'm thirsty.

A some $\mathrm{B}$ a $\mathrm{C}$ any $\mathrm{D}$ the

10 Let's go into garden. It's sunny outside.

A a B any $\mathrm{C}-\mathrm{D}$ the

$11 \mathrm{He}$ 's_ for the next train.

A looking B waiting C listening D paying

12 Mark his car last week.

A cleaned B did clean C has cleaned D is cleaning

13 I bought some lovely red today.

A cabbages B cucumbers $\mathrm{C}$ bananas D apples

14 Which bus _ for when I saw you this morning?

A did you wait B had you waited C were you waiting D have you waited

15 Where _ you like to go tonight?

A do $\mathrm{B}$ would $\mathrm{C}$ are $\mathrm{D}$ can

16 That's the film I've ever seen!

A worse $\mathrm{B}$ worst $\mathrm{C}$ baddest $\mathrm{D}$ most bad

17 My dad _ his car yet.

A hasn't sold B didn't sell C doesn't sell D wasn't sold

18 I've been a doctor _ fifteen years.

A since $\mathrm{B}$ for $\mathrm{C}$ until $\mathrm{D}$ by

19 Look at the sky. It rain.

A will $\mathrm{B}$ can $\mathrm{C}$ is going to $\mathrm{D}$ does

20 If I this homework, the teacher will be angry!

A am not finishing B won't finish $\mathrm{C}$ don't finish D didn't finished

21 This book is even _than the last one!

A most boring $\mathrm{B}$ boringer $\mathrm{C}$ more boring $\mathrm{D}$ far boring

22 I'll meet you __ I finish work. 
$\mathrm{A}$ if $\mathrm{B}$ when $\mathrm{C}$ as $\mathrm{D}$ so

23 We're getting married__ March.

$\mathrm{A}$ in $\mathrm{B}$ on $\mathrm{C}$ at $\mathrm{D}$ by

24 If you __steak for a long time, it goes hard.

A cook B are cooking C have cooked D cooked

25 I you outside the cinema, OK?

A 'll see B am going to see C am seeing D see

26 I ___ not be home this evening. Phone me on my mobile.

A can B could C may D should

27 The criminal _outside the hotel last night.

A was caught $B$ has been caught $C$ is caught $D$ caught

28 He asked me if I a lift home.

A wanted B want C was wanting D had wanted

29 If I older, I'd be able to vote in elections.

A had B am C were D have

30 You go to the supermarket this afternoon. I've already been.

A mustn't B can't C needn't D won't

31 Kathy drives _than her sister.

A more carefully B more careful C carefully D most carefully

32 The _near our village is beautiful.

A country B woods C view D countryside

33 I'm _ I can't help you with that.

A apologise $B$ afraid $C$ regret $D$ sad

34 It was really _ this morning. I couldn't see anything on the roads.

A cloudy B sunny C icy D foggy

35 Can you look__ my dog while I'm away?

A for $\mathrm{B}$ at $\mathrm{C}$ to $\mathrm{D}$ after

36 If I'd started the work earlier I it by now.

A would finish B had finished $C$ will finish D would have finished

37 This time next year I in Madrid.

A am working $\mathrm{B}$ will work $\mathrm{C}$ will be working $\mathrm{D}$ work

38 I wish he __ in front of our gate. It's very annoying.

A won't park B wouldn't park C doesn't park D can't park

39 He said he'd seen her the __ night.

A last B before $\mathrm{C}$ previous $\mathrm{D}$ earlier

$40 \mathrm{I}$ agreed to go out. I haven't got any money!

A mustn't have B shouldn't have

Published by SCHOLINK INC. 
C couldn't have D wouldn't have

41 It was good__about her recovery, wasn't it?

A information B words $\mathrm{C}$ news D reports

42 I the report by 5.00 p.m. You can have it then.

A have finished $\mathrm{B}$ will have finished

$\mathrm{C}$ finish $\mathrm{D}$ am finishing

43 Because of the snow the teachers all the students to go home early.

A said B made C told D demanded

44 Thanks for the meal! It was

A delighted $\mathrm{B}$ delicious $\mathrm{C}$ disgusting

D distasteful

45 Look! Our head teacher on TV right now!

$\mathrm{A}$ is being interviewed $\mathrm{B}$ is been interviewed

$\mathrm{C}$ is interviewing $\mathrm{D}$ is interviewed

46 It's _ to drive a car over $115 \mathrm{~km} / \mathrm{h}$ in the

UK.

A unlegal B illegal C dislegal D legaless

47 There's a lot of rubbish in the garden I need to get of.

A lost $\mathrm{B}$ rid $\mathrm{C}$ cleared $\mathrm{D}$ taken

48 I'm afraid it's time we

A leave $B$ must leave $C$ are leaving D left

49 He wondered what

A is the time? $\mathrm{B}$ the time was $\mathrm{C}$ was the time $\mathrm{D}$ is the time?

50 They_our salaries by $5 \%$.

A rose $B$ made up $C$ raised D lifted

\section{Reading}

Read the text.

\section{Saucy dragons}

Levi Roots, a reggae singer from Jamaica, has a big smile on his face these days. In case you missed it, Levi recently appeared on the famous reality show for people with business ideas, Dragon's Den. The participants have to persuade the team of business experts that their ideas are excellent and hope that two or more of the team will decide to invest money in their business idea.

Levi did just that!

The singer, who has been a successful music artist for several years, also sells something he calls "Reggae, reggae sauce". It is made using special secret ingredients from his grandmother and is a hot Jamaican sauce that is eaten with meat. Until now it has only been possible to buy the sauce from Levi's website or once a year at the famous Notting Hill carnival. But now, thanks to the TV 
programme, that is all going to change!

Levi presented his business idea to the team and started with a catchy reggae song about the sauce to make them sit up and listen. He certainly got their attention! He then described his plans for the sauce. This part of his presentation didn't go so well. He made mistakes with his figures, saying that he already had an order for the sauce of 2 and a half million when in fact he meant 2 and a half thousand! But, the team were still interested and amazingly, two of the team offered to give $£ 50,000$ to the plan in exchange for $40 \%$ of the company. Mr Roots was ecstatic!

Levi is even happier today. It seems that two of the biggest supermarket chains in the UK are interested in having the sauce on their shelves. In addition to this, Levi is recording the "Reggae, reggae sauce" song and we will soon be able to buy or download this. "It's all about putting music into food", says Levi with a big, big smile on his face! And music and food will probably make him a very rich man indeed!

1 Are the sentences true or false?

1) At the moment Levi isn't very happy.

2) Levi sells something we can eat.

3) His song is a big success.

4) He sang his song on TV.

5) Some supermarkets want to sell his product.

2 Choose the best answers.

1) Dragon's Den is a show about

A cooking.

B new business ideas.

C famous people.

2) To make the sauce

A you have to go to Notting Hill.

B you have to ask a member of Levi's family.

$\mathrm{C}$ you need a good recipe book.

3) When Levi presented his idea

A he finished with a song.

$\mathrm{B}$ two and a half million people were watching.

$\mathrm{C}$ he talked about the wrong figures.

4) Some people on the team

A own supermarkets.

B didn't like the taste.

C bought part of Levi's company.

5) Today Levi

$\mathrm{A}$ is a millionaire.

Published by SCHOLINK INC. 
B has two things he can profit from.

C prefers music to food.

\section{Writing}

Imagine you have just returned from a two-week holiday. Write an e-mail to your friend telling him/her about the holiday. Include information about the journey, where you stayed, what you did and the people you met.

\section{Answer Key}

Grammar and Vocabulary

$\begin{array}{llllllllllllllll}1 \mathrm{C} & 2 \mathrm{~A} & 3 \mathrm{~B} & 4 \mathrm{D} & 5 \mathrm{~B} & 6 \mathrm{~B} & 7 \mathrm{D} & 8 \mathrm{C} & 9 \mathrm{C} & 10 \mathrm{D} & 11 \mathrm{~B} & 12 \mathrm{~A} & 13 \mathrm{D} & 14 \mathrm{C} & 15 \mathrm{~B} \\ 16 \mathrm{~B} & 17 \mathrm{~A} & 18 \mathrm{~B} & 19 \mathrm{C} & 20 \mathrm{C} & 21 \mathrm{C} & 22 \mathrm{~B} & 23 \mathrm{~A} & 24 \mathrm{~A} & 25 \mathrm{~A} & 26 \mathrm{C} & 27 \mathrm{~A} & 28 \mathrm{~A} & 29 \\ \mathrm{C} & 30 \mathrm{C} & 31 \mathrm{~A} & 32 \mathrm{D} & 33 \mathrm{~B} & 34 \mathrm{D} & 35 \mathrm{D} & 36 \mathrm{D} & 37 \mathrm{C} & 38 & \mathrm{~B} & 39 \mathrm{C} & 40 \mathrm{~B} & 41 \mathrm{C} \\ 42 \mathrm{~B} & 43 \mathrm{C} & 44 \mathrm{~B} & 45 \mathrm{~A} & 46 \mathrm{~B} & 47 \mathrm{~B} & 48 \mathrm{D} & 49 \mathrm{~B} & 50 \mathrm{C} & & & & \end{array}$

\section{Reading}

1
$2 \mathrm{~T}$
$3 \mathrm{~F}$
$4 \mathrm{~T}$
$5 \mathrm{~T}$

2
2 B
$3 \mathrm{C}$
$4 \mathrm{C}$
$5 \mathrm{~B}$

\section{Writing}

Content (maximum 4 points)

- 1 point for each point included.

- $1 / 2$ point if part of a point is included but not developed.

Form (maximum 2 points)

- 2 points for correct format.

- 1 point if only part of format is used.

- 0 points if format is not used at all.

Range (maximum 2 points)

- 2 points for using a good range of vocabulary and structures.

- 1 point for using a reasonable range of vocabulary and structures.

- 0 points for using a poor range of vocabulary and structures. 
Accuracy (maximum 2 points)

- 2 points for accuracy over $80 \%$.

- 1 point for accuracy between 70 and $80 \%$.

\section{Appendix 2}

\section{Test of Vocabulary}

Write the definitions of the following words (either in English or in Farsi) in the spaces provided.

1- Sign

2- Warning

3- $\quad$ Aisle

4- Carefully

5- Stay

6- Kindly

7- Fly

8- Curtain

9- Quickly

10- Dream

11- Laugh

12- Village

13- Church

14- Cemetery

15- Grave

16- Trick

17- Travel

18- Shake

19- Vacation

20- Trailer

21- Patient

22- Cross

23- Offer

24- Fix

25- Faucet

26- Plumber

27- Bill

28- Mustache

29- Step-brother

30- Proudly 

31- Polite
32- Naughty
33- Shout
34- Wave
35- Step
36- Fight
37- Hit
38- Hold
39- Knock over
40- Bite
41- Photographer
42- Injection
43- Get into
44- Interesting
45- famous
46- frightened
47- bottom
48- reach
49- country
50- bathtub
51- straight
52- crowded
53- serve
54- terrible
55- present
56- matter
57- sailor
58- several
59- port
60- shallow 